\title{
The Trinity as a Challenge to Christian-Muslim Dialogue in Nicholas of Cusa: Nicholas of Cusa's Philosophical Translation of Trinitarian Faith as a Response to Islamic Rejection
}

\author{
Felix Resch
}

Nicholas of Cusa provides an interesting example of fostering a ChristianMuslim dialogue. ${ }^{1}$ Thus, the focus of this essay is on Cusa's method of dealing philosophically with the Islamic accusations raised against the Christian doctrine of the Trinity. To explore this topic, I will first of all contrast contemporary interreligious dialogue with Cusa's interreligious dialogue, in order to get an idea of what the latter aims at. Then, I will turn to discuss the logical or philosophical objections against the Trinity mentioned in the Qur'an, after which I will examine the ways that Christians could respond to these accusations. Among the different options available, the kerygmatic trinitarian theology, which reduces the three divine persons to proper names of three individual entities, will draw particular attention. Therefore, the philosophical and theological meanings of proper names will also have to be analyzed, in order to understand why Cusa saw the need to translate trinitarian proper names into philosophical concepts, despite the fact that naming the trinitarian God was still important for him.

In our globalized world, characterized by the decline of social, national, political, and religious borders, isolation turns out to be more and more of an

1 Given that there is vast literature on this issue in general, I will just mention some works: Tom Kerger and Walter Andreas Euler, eds., Cusanus und der Islam, 1st ed. (Trier: Paulinus, 2010); Rudolf Haubst, ed., Der Friede unter den Religionen nach Nikolaus von Kues, thematic issue of Mitteilungen und Forschungsbeiträge der Cusanus-Gesellschaft 16 (1984); Walter Andreas Euler, Unitas et Pax: Religionsvergleich bei Raimundus Lullus und Nikolaus von Kues, 2nd ed., Religionswissenschaftliche Studien, 15 (Würzburg: Echter, 1995); Tibor Bakos, On Faith, Rationality and the Other in the Late Middle Ages. A Study of Nicholas of Cusa's manuductive approach to Islam. Dissertation presented to fulfill the requirements for the degree of Doctor (Ph.D.) in Philosophy (Leuven: unpublished dissertation, 2003); Markus Riedenauer, Pluralität und Rationalität: Die Herausforderung der Vernunft durch religiöse und kulturelle Vielfalt nach Nikolaus Cusanus, Theologie und Frieden, 32 (Stuttgart: Kohlhammer, 2007). 
impossible option. As a consequence, each collective entity is forced to adopt an attitude toward the others. Rather than resorting to confrontation, indifference, or surrender, dialogue seems to be the most useful attitude to adopt in order to respect others while remaining faithful to oneself. In our post-9/11 world, we see the urgent need for religions to search for common ground in order to overcome misunderstandings and hostilities, which often lead to violence. Apart from fundamentalists, most religious leaders agree that interreligious dialogue is preferable to forced conversion, as dialogue is used to foster mutual understanding. ${ }^{2}$ Proselytism and syncretism are both excluded as alternatives. $^{3}$

I would call this a hermeneutical dialogue with social implications, enabled by the rise of the modern secular state. ${ }^{4}$ Modern Western societies are based on religious plurality, where due to the secular constitutional and judicial framework, religious diversity must no longer lead to political conflicts. As we know, the origins of the modern secular state are deeply rooted in European history, especially in the experiences of the bloody wars of religion in the Early Modern Age. ${ }^{5}$ That is why in the Late Middle Ages, when religious unity and social peace were still regarded as inseparable, religious diversity was consequently interpreted as a danger for society. Conversely, achieving religious unity was seen as a necessary condition for social peace. Obviously, there are different ways of achieving religious unity. The first method, to conquer or submit to another religion, lost a lot of popularity in the fifteenth

2 A good example of trying to foster mutual theological understanding between Christians and Muslims is Christian W. Troll, Muslime fragen, Christen antworten, Topos-plus-Taschenbücher, 489, 2nd ed. (Regensburg: Pustet, 2004).

3 An interesting example of a grassroots interreligious dialogue is the French organization 'Coexister, founded in 2009 by young Christians, Jews, and Muslims under the slogan "Diversité dans la foi, Unité dans l'action" (http://www.coexister.fr/association.html, accessed December 4, 2012).

4 Ernst-Wolfgang Böckenförde's famous dictum points out that the liberal, secularized state is based on presuppositions that cannot be guaranteed on their own (Ernst-Wolfgang Böckenförde, Staat, Gesellschaft, Freiheit: Studien zur Staatstheorie und zum Verfassungsrecht (Frankfurt: Suhrkamp, 1976), 6o). Hence, Jürgen Habermas insists on the importance of religions as a resource even for a secular society. See Jürgen Habermas, "Glauben und Wissen," in Friedenspreis des Deutschen Buchhandels 2001-Jürgen Habermas, ed. Börsenverein des deutschen Buchhandels, 9-15, especially 13. To fulfill this task, religions are requested to translate their religious contents into a secular language (12-13).

5 Böckenförde, Staat, Gesellschaft, Freiheit, 42-64. 
century. ${ }^{6}$ Thus, in his letter to John of Segovia in 1454, Nicholas of Cusa agrees with his interlocutor that military actions against the expanding Turks should be replaced by rational argumentation, in order to convince the Muslims of central Christian doctrines like the Trinity and the hypostatic union. ${ }^{7}$ In the same work he mentions his dialogue De pace fidei, written one year before, where he had attempted to put such a program into practice. ${ }^{8}$

Since such an endeavor entails the risk of being refuted by the other religion, this attitude presupposes a deep conviction of the rational superiority of Christian faith, as well as an assurance of the importance of a rational discussion between Christians and Muslims, with the aim of defeating the latter through rationality. ${ }^{9}$ Contrary to hermeneutical dialogues, I would call this an

6 On the decreasing approval of combating the Turks after the fall of Constantinople, see Thomas M. Izbicki, "The Possibility of Dialogue with Islam in the Fifteenth Century," in Nicholas of Cusa in Search of God and Wisdom, ed. Gerald Christianson and Thomas M. Izbicki (Leiden: Brill, 1991), 175-185 at 175 .

7 Nicholas of Cusa, "Epistula ad Ioannem de Segobia 2," in Nicolai de Cusa opera omnia iussu et auctoritate academiae litterarum Heidelbergensis ad codicum fidem edita: Volumen VII (Hamburg: Meiner, 1970). In his dialogue with a Persian, held in 1391, the Byzantine Emperor Manuel II considers faith as a fruit of the soul and not of the body (Manuel II. Palaiologos, Dialoge mit einem Muslim, I: Kommentierte griechisch-deutsche Textausgabe von Karl Förstel, Corpus Islamo-christianum: Series Graeca, 4 (Würzburg-Altenberge, 1993), VII. Dialog 1.6, 240-243). Instead of violence, speech and reasoning should be used as tools to convince someone (240-243). On this issue see Pope Benedict's well-known Regensburg lecture held on September 12, 2006, and edited in Benedikt XVI, Glaube und Vernunft. Die Regensburger Vorlesung: Vollständige Ausgabe, commen. Gesine Schwan, Adel Theodor Khoury, and Karl Kardinal Lehmann (Freiburg: Herder, 2006), 15-17. An interesting comparison between Nicholas of Cusa, Manuel II, and Pope Benedict XVI is given in Walter Andreas Euler, Papst Benedikt XVI, Kaiser Manuel II und Kardinal Nikolaus von Kues: Das Verhältnis von Glaube und Vernunft und die christliche Sicht des Islams, 1st ed., Kleine Schriften der Cusanus-Gesellschaft, Heft 17 (Trier: Paulinus, 2007).

8 The Prologue narrates the deep impact the fall of Constantinople has on the author (De pace fidei 1, n. 1 [h VII]) who begs God to end the bloody fights and to overcome religious differences. Thus, God convokes a heavenly council of wise men representing different cultures (3, n. 9). Despite the Christian setting, which is exemplified by the chair of the divine Logos and the Apostles Peter and Paul, all the discussions are held in a rational and peaceful way.

9 I agree with Markus Riedenauer that according to Cusanus, philosophical rationality seems to be the adequate basis for an interreligious dialogue (Markus Riedenauer, Pluralität und Rationalität: Die Herausforderung der Vernunft durch religiöse und kulturelle Vielfalt nach Nikolaus Cusanus, Theologie und Frieden, 32 (Stuttgart: Kohlhammer, 2007), 103). As Thomas M. Izbicki puts it: "Dissent on important matters of belief or practice, especially dissent based on a clear, informed conscience, was almost incomprehensible to the intellectual leaders of Europe" (Izbicki, "The Possibility of Dialogue with Islam in the Fifteenth Century," 183). 
alethic dialogue, the main goal of which is not to give testimony to one's own faith without commenting on the other, but rather, to scrutinize the articles of faith - in particular the Trinity and the hypostatic union - through natural reason. This is possible because the Christian and Muslim religions are not mere psychological phenomena, but instead entail an alethic dimension ${ }^{10}$ and raise absolute and universal truth claims. ${ }^{11}$

Given that Christians and Muslims hold contradictory positions toward God's personality and revelation, both positions cannot be true; according to the law of non-contradiction, one must be true and one must be false. Within this logical framework, the epistemic challenge consists in finding out which position is in fact true. ${ }^{12}$

\section{The Logical and Doxological Accusations Raised against the Doctrine of Christian Trinity in the Qur'an}

To better understand how Cusa's trinitarian faith was challenged by Islam, I cite one of the most significant Qur'anic rejections of the Christian doctrine of the Trinity, which is found in Sura 4:171-172:

People of the Book, do not transgress the bounds of your religion. Speak nothing but the truth about God. The Messiah, Jesus the son of Mary, was no more than God's apostle and His Word which he cast to Mary: a spirit from Him. So believe in God and His apostles and do not say: 'Three.' Forbear, and it shall be better for you. God is but one God. God forbid that He should have a son! His is all that heavens and the earth contain. God is the all sufficient protector. The Messiah does not disdain to be a servant

10 Of course, they entail other dimensions as well, like an aesthetical or ethical one, the latter of which is underlined by Hans Küng's well-known 'Global Ethic.' See Küng, Projekt Weltethos (Munich: Piper, 1990).

11 On the absolute and universal truth claims of the three monotheistic world religions, see Markus Enders, “'Denn Gott ist die Wahrheit' (Koran 22,6 63; 31.30): Anmerkungen zum Wahrheitsverständnis und zu den Wahrheitsansprüchen der drei monotheistischen Weltreligionen," Philotheos. International Journal for Philosophy and Theology 12 (2012): 17-35; on the importance of philosophy in interreligious dialogue, see Josef Schmidt, S. J., "Zur Bedeutung der Philosophie im Religionsdialog," Jahrbuch für Religionsphilosophie 9 (2010): 9-24.

12 On the systematic and historical aspect of conflicting truth claims in the Renaissance, see the excellent epilogue in Paul Richard Blum, Philosophy of Religion in the Renaissance (Farnham: Ashgate, 2011), 177-183. 
of God, nor do the angels who are nearest to Him. Those who through arrogance disdain His service shall be brought before Him. ${ }^{13}$

With respect to content, we find two accusations raised against the Christians in this passage. First, the doctrine of the Trinity is incompatible with God's unity. Second, the christological doctrine of the hypostatic union, or Jesus Christ's divine sonship, is incompatible with God's transcendence. Both are logical objections assuming a formal contradiction between the core doctrines of the Christian faith and God's true nature. Finally, both correspond to Islam's doxological accusation of shirk, i.e., associating someone or something with God, ${ }^{14}$ which is contrary to tawhid, the traditional Islamic confession of God's unity. ${ }^{15}$

It is interesting to observe that in Sura 4:171-172, the Trinity doctrine is only rejected, but not elucidated in detail. Rather, the emphasis lies on the interpretation of Jesus Christ. On the one hand, Jesus, who is conceived in a miraculous way by the Virgin Mary, ${ }^{16}$ is said to deserve the title 'Messiah. ${ }^{17}$ On the other hand, Christians are accused of assigning a son to God and divinizing Jesus, although according to the Qur'an, he only claimed to be a servant of God. The sura underlines the absolute transcendence of God, who possesses "all that the heavens and the earth contain." Each being depends on his will, because all are created by him. ${ }^{18}$ Hence, the general relationship between all creatures and their creator can never be replaced by a special relationship between the son and his father.

Another text, Sura 5:116-118, deepens the impression that Christian doctrines do not remain faithful to Jesus Christ's own teaching:

13 Sura 4:171-172. All English translations of Qur'anic suras are taken from N. J. Dawood, The Koran: Translated with notes by N. J. Dawood, 5 th revised ed. (London: Penguin, 1990).

14 On this issue, see Muhammad Ibrahim H. I. Surty, The Qur'ān and Al-Shirk (Polytheism), 2nd revised ed. (London: Ta-Ha, 1990). The doxological accusation is also raised against the ecclesiastic hierarchy: "They make of their clerics and their monks, and of the Messiah, the son of Mary, Lords besides God; though they were ordered to serve one God only" (Sura 9:31).

15 Sandra Toenies Keating, "'Say Not Three': Some Early Christian Responses to Muslim Questions on the Trinity," The Thomist 74 (2010): 85-104 at 86.

16 Khoury states that it is his virgin birth that makes Jesus so pure that he can be called 'spirit from God' (Adel Theodor Khoury, Der Koran: Übersetzt und kommentiert von Adel Theodor Khoury (Gütersloh: Gütersloher Verlagshaus, 2007), 155, note 4, 171).

17 On Jesus' peculiar prophetic mission, see Sura 3:48-55.

18 E.g., Sura $36: 81-82$. 
Then God will say: "Jesus, son of Mary, did you ever say to mankind: 'Worship me and my mother as gods besides God?'” "Glory to You," he will answer, "how could I ever say that to which I have no right? If I had ever said so, You would have surely known it. You know what is in my mind, but I know not what is in Yours. You alone know what is hidden. I told them only what You bade me. I said: 'Serve God, my Lord and your Lord.' I watched over them while living in their midst, and ever since You took me to Yourself, You have been watching over them. You are the witness of all things. If You punish them, they surely are Your servants; and if You forgive them, surely You are mighty and wise. ${ }^{19}$

In this passage, Jesus Christ is presented as God's prophet, who claims that neither he nor his mother is to be worshipped as God. ${ }^{20}$ Obviously, this sura rejects the idea of a familial Trinity made up of Father, Mother, and Son. ${ }^{21}$ However, Sura 5:72-73 makes it clear that any type of Trinity is considered a violation of tawhid, because being reduced to one of three persons, God is no longer one:

Unbelievers are those that say: "God is the Messiah, the son of Mary." For the Messiah himself said: "Children of Israel, serve God, my Lord and your Lord." He that worships other gods besides God, God will deny him Paradise, and Hell shall be his home. None shall help the evil-doers. Unbelievers are those that say: "God is one of three." There is but one God. If they do not desist from so saying, those of them that disbelieve shall be sternly punished.22

This sura leaves no doubt that unbelievers, i.e. everyone committing shirk, shall be punished in hell.

\section{How Should Christians Respond?}

There are several different ways to respond to such accusations. The first option would be to surrender. Seeing no possibility of refuting the Islamic objection

\footnotetext{
19 Sura 5:116-118.

20 Sura 5:17 repeats that Jesus and Mary are creatures depending totally on God's will: "Say: 'Who could prevent God, if He so willed, from destroying the Messiah, the son of Mary, his mother, and all the people of the earth? [...]."

21 On this issue see Khoury, Der Koran, 155, note 4,171.

22 Sura $5: 72-73$.
} 
against the trinitarian doctrine, the Christian interlocutor could admit that the assertion that God is triune is incompatible with the assertion that God is one. Remaining faithful to the latter, he would consequently give up the first. ${ }^{23}$ Such a strategy could be motivated by a strong admiration for the monotheistic heritage, while underestimating the rationality of trinitarian belief. It is evident that this option abandons orthodox Christian faith. ${ }^{24}$

A second option would be confrontation. Instead of trying to refute the Islamic objection against trinitarian doctrine, the Christian interlocutor could begin to distract the Muslim's attention by raising other objections against Islam, or simply enter into polemics. Obviously, this option would turn out to be an intellectual non-starter.

The third option, however, seems to be much more subtle. Apparently, indifference can help to deal with accusations raised against the trinitarian doctrine. Philosophical or logical objections could seduce the Christian interlocutor to withdraw from a speculative trinitarian theology by taking refuge in a mere kerygmatic trinitarian theology. ${ }^{25}$ Instead of refuting the Islamic attack, the Christian could remind the Muslim interrogator of the salvific history where God reveals himself as trinitarian. This includes a shift in emphasis from the immanent to the economic Trinity. Rediscovering the particular role each divine figure plays in the salvific history, this option takes 'Father,' 'Son,' and 'Holy Spirit' primarily as proper names of individual entities.

In the next section, I will discuss the philosophical and theological meanings of proper names in order to show why they are not sufficient for an adequate understanding of the Trinity. This will also elucidate why Cusa saw himself challenged to translate trinitarian proper names into philosophical concepts.

\section{Philosophical and Theological Considerations on Proper Names}

In the last few decades, proper names have drawn a lot of philosophical interest, especially by analytic philosophers. One of the most interesting theories

23 On the development of non-trinitarian theologies see Gavin D'Costa, "The Trinity in Interreligious Dialogues," in The Oxford Handbook of the Trinity, ed. Gilles Emery, O. P. and Matthew Levering (Oxford: Oxford University Press, 2011), 573-585 at 574-576.

24 The modalistic view arguing that 'Father,' 'Son,' and 'Holy Ghost' are only three names for one and the same entity without any real distinction boils down to the same heterodox result.

25 E.g., Jürgen Moltmann, Trinität und Reich Gottes: Zur Gotteslehre (Munich: Kaiser, 1980); Barbara Andrade, Gott mitten unter uns: Entwurf einer kerygmatischen Trinitätstheologie, Europäische Hochschulschriften, 631 (Frankfurt: Lang, 1998). 
is Saul A. Kripke's Theory of Reference. In his lectures Naming and Necessity, held in January of 1970 at Princeton University, he treats proper names as rigid designators. ${ }^{26}$ While rejecting Gottlob Frege's and Bertrand Russell's reduction of proper names to definite descriptions, Kripke points out the essential role proper names play to guarantee transworld identity:

One of the intuitive theses I will maintain in these talks is that names are rigid designators. Certainly, they seem to satisfy the intuitive test mentioned above: although someone other than the U.s. President in 1970 might have been the U.s. President in 1970 (e.g., Humphrey might have), no one other than Nixon might have been Nixon. In the same way, a designator rigidly designates a certain object if it designates that object wherever the object exists; [...]. [...] Those who have argued that to make sense of the notion of rigid designators, we must antecedently make sense of 'criteria of transworld identity' have precisely reversed the cart and the horse; it is because we can refer (rigidly) to Nixon, and stipulate that we are speaking of what might have happened to him (under certain circumstances), that 'transworld identifications' are unproblematic in such cases. ${ }^{27}$

Kripke argues that the main reason for searching for criteria or descriptions to identify an object is the confusion of the metaphysical and the epistemological dimension, or, in other terms, of necessity and a prioricity. ${ }^{28}$ If one holds that objects are identified in all possible worlds by a property or a set of properties known a priori, he ignores that "( 1 ) Generally, things aren't 'found out' about a counterfactual situation, they are stipulated; (2) possible worlds need not be given purely qualitatively, as if we were looking at them through a telescope."29 What Kripke offers, therefore, is a different view on beings, which is not driven by an attempt to reduce individual entities to bundles of properties, but rather, by a desire to reestablish the ontological primacy of the substance. ${ }^{30}$ Hence, he tries to fix reference by what he calls an "initial "baptism."'31 Here, it is the name "'passed from link to link" 32 that marks exactly an individual being. Recently,

\footnotetext{
26 Saul A. Kripke, Naming and Necessity (Oxford: Blackwell, 1981), 48.

27 Ibid., 48-49.

28 Ibid., 49 .

29 Ibid., 49-50.

30 Simultaneously, he defends the ontological primacy of actual beings over possible states of affairs.

$31 \quad$ Kripke, Naming and Necessity, 96.

32 Ibid., 96 .
} 
Kripke's insistence on proper names has been adopted by Robert Spaemann for the purposes of philosophical theology. In his speech Was ist das, 'quod omnes dicunt deum'? held in March of 2011 in Tübingen, Spaemann attempts to treat the word 'God' as a proper name, ${ }^{33}$ arguing that its reference is fixed by a causal chain dating back to a kind of 'initial baptism.' According to Spaemann, we can only believe that this causal chain is without a gap. ${ }^{34}$

In his book Trinität und Reich Gottes, published in 1980, Jürgen Moltmann treats even the trinitarian names as proper names. ${ }^{35}$ Consequently, he rejects the concepts of substance and subject to explain the unity of the three trinitarian figures. Rather, he considers the Father, the Son, and the Holy Spirit as three different subjects playing different roles in the trinitarian history. ${ }^{36}$ According to Moltmann, even the unity of these three must be understood in a trinitarian way: the Father as the origin, the Son as the mutual consent, and the Holy Spirit as the glorifying community. ${ }^{37}$ It is hard to see how this kind of social trinity avoids the danger of tritheism. ${ }^{38}$

Taking the Father, the Son, and the Holy Spirit as three numerically different subjects who share one common predicate 'God' is incompatible with monotheism. In this case, God would be reduced to a mere universal, thus the Islamic objections would be justifiable. The only way I see how to refute these objections and make sure that Christian trinitarian faith is indeed monotheistic is through an alethic dialogue, which still remains as a fourth option for Christians to turn to when responding to the Qur'anic accusations. Since Muslims do not share the same source of revelation, Christians have to translate the revealed proper names-'Father,' 'Son,' and 'Holy Spirit' - into philosophical concepts, in order to foster communicability and claim absolute and universal truth.

In the following section I will therefore focus on Cusa's translation of the trinitarian proper names into philosophical concepts, within the framework of his dialogue with Islam.

33 Robert Spaemann, "Was ist das, 'quod omnes dicunt deum'?, in Gottesbeweise als Herausforderung für die moderne Vernunft, ed. Thomas Buchheim, Friedrich Hermanni, Axel Hutter, and Christoph Schwöbel, Collegium Metaphysicum, 4 (Tübingen: Mohr Siebeck, 2012), 33-45 at 37 .

34 Spaemann, "Was ist das, 'quod omnes dicunt deum'?," 37.

35 Moltmann, Trinität und Reich Gottes: Zur Gotteslehre, 179-194.

36 Ibid., 173-174.

37 Ibid., 194.

38 On tritheism, see Christophe Erismann, "The Trinity, Universals, and Particular Substances: Philoponus and Roscelin," Traditio 63 (2008): 277-305. 


\section{Cusa's Translation of Trinitarian Proper Names}

Generally speaking, in Cusa's works we find two different approaches to Islam. First, there is his philosophical approach, the manuductio of Muslims toward the Mystery of the Trinity, especially in De pace fidei and parts of Cribratio Alkorani. Second, there is his exegetical approach, the pia interpretatio of the Qur'an in Cribratio Alkorani. ${ }^{39}$ In this essay, I will only focus on the first one, for which I hold that Cusa uses a double strategy: on the one hand, he shares the Muslim concern about God's unity, while on the other hand, he attempts to convince the Muslims that God is in fact triune.

In Chapter 8 of De pace fidei, the Chaldean interlocutor picks up the traditional accusation of shirk: "But the view that God has a Son and that He partakes of the deity - this the Arabs (and many [others] along with them) call into question." 40 Thus, the Divine Word as Cusa's spokesman is forced to translate the trinitarian proper names into philosophical concepts:

Some [writers] name Oneness Father, Equality Son, and Union Holy Spirit because these terms, though not proper, nonetheless signify the Trinity suitably. For the Son is from the Father; and Love, or Spirit, is from Oneness and from the Son's Equality. For the nature of the Father passes over into a certain equality in the Son; therefore, Love-and-Union arises from Oneness and Equality. And if simpler terms could be found, they would be more fitting - as are Oneness, Itness, and Sameness. For these terms seem to explicate better the most fecund simplicity of the essence. And since in the essence of the rational soul there is a certain fecundity_viz., mind, wisdom, and love, or will—notice that mind, of itself, begets understanding or wisdom, from which [proceeds] will, or love.

39 On this issue, see Tom Kerger, Pia interpretatio: Vier christliche Theologen im Gespräch mit dem Islam, 1st ed., Trierer theologische Studien, 75 (Trier: Paulinus, 2010); Ludwig Hagemann, Der Kur'än in Verständnis und Kritik bei Nikolaus von Kues: Ein Beitrag zur Erhellung islämisch-christlicher Geschichte, Frankfurter theologische Studien, 21 (Frankfurt: Knecht, 1976); Jasper Hopkins, "The Role of pia interpretatio in Nicholas of Cusa's Hermeneutical Approach to the Koran," in Concordia discors, ed. Gregorio Piaia (Padua: Antenore, 1993), 251-273.

40 Jasper Hopkins, Nicholas of Cusa's De pace fidei and Cribratio Alkorani: Translation and Analysis, 2nd ed. (Minneapolis, MN: Banning, 1994), 645. De pace fidei 8, n. 23: "Sed quod Deus habeat filium et participem in deitate, hoc impugnant Arabes et multi cum ipsis." 
And this trinity in the soul's oneness of essence is a fecundity which [the soul] has in likeness to the most fecund uncreated Trinity. ${ }^{41}$

It is noteworthy that within the henological-apophatic framework of Cusanian metaphysics, even the names of the trinitarian characters are not adequate to express the ineffable mystery of the Trinity. ${ }^{42}$ This is perhaps one of the most striking facts for a Christian philosopher. ${ }^{43}$ Unlike Thomas Aquinas, ${ }^{44}$ Cusa explicitly states that the trinitarian names, though 'suitable' (convenienter), are not proper (non sint proprii). Philosophical concepts like 'Oneness,' 'Equality,' and 'Union,' or alternatively 'Oneness,' 'Itness,' and 'Sameness,' are much more precise because they are simpler and less anthropomorphic. This triadunitas, aequalitas, and conexio or concordia - goes back to Augustine's De doctrina christian $a^{45}$ and was developed further by the School of Chartres,

41 Ibid., 645-646. De pace fidei 8, n. 24: "Nominant aliqui unitatem Patrem, aequalitatem Filium, et nexum Spiritum Sanctum; quia illi termini etsi non sint proprii, tamen convenienter significant trinitatem. Nam de Patre Filius, et ab unitate et aequalitate Filii amor seu Spiritus. Transit enim natura Patris in quandam aequalitatem in Filio. Quare amor et nexus ab unitate et aequalitate exoritur. Et si simpliciores termini reperiri possent, aptiores forent, ut est unitas, iditas et idemptitas. Hii enim termini magis videntur fecundissimam essentiae simplicitatem explicare. Et attende, cum in essentia rationalis animae sit quaedam fecunditas, scilicet mens, sapientia et amor seu voluntas, quoniam mens ex se exerit intellectum seu sapientiam, ex quibus voluntas seu amor, et est haec trinitas in unitate essentiae animae fecunditas quam habet in similitudine fecundissimae increatae trinitatis."

42 A similar position is held in De docta ign. I, 9 (h I), Sermo XXII (h XVI4 n. 21), and De non aliud 5 (h XII).

43 See Gilson's reaction in Etienne Gilson, Die Metamorphosen des Gottesreiches, trans. U. Behler (Munich: Schöningh, 1959), 169: "Unmöglich kann man sich dem Buchstaben des Dogmas gegenüber noch fügsamer zeigen. Die Einheit im Glauben, von der Nikolaus träumt, wird es nicht einmal mehr erfordern, daß man vom Vater, Sohn und Heiligen Geist spricht."

44 Thomas, "STh I q. 33 a. 2," in Editio Leonina: Sancti Thomae Aquinatis doctoris angelici Opera omnia iussu impensaque Leonis XIII. P.M. edita: Tomus quartus: Pars prima Summae theologiae: A quaestione 1 ad quaestionem XLIX ad codices manuscriptos vaticanos exacta cum commentariis Thomae de Vio Caietani Ordinis Praedicatorum S.R.E. Cardinalis cura et studio fratrum eiusdem ordinis (Rome: Ex Typographia Polyglotta S. C. de Propaganda Fide, 1888), 359 .

45 Augustine, "De doctrina christiana I, V, 5," in Aurelii Augustini Opera: Pars IV,1: Sancti Aurelii Augustini De doctrina christiana-De vera religione, ed. Josef Martin, Corpus Christianorum: Series Latina, 32 (Turnhout: Brepols, 1962), 9. 
especially Thierry of Chartres. ${ }^{46}$ In his main work, De docta ignorantia, Cusa dedicates two chapters to this triad in order to elucidate the intradivine processions. ${ }^{47}$ There he also mentions the triad unitas, iditas, and identitas. ${ }^{48}$

The passage cited above from De pace fidei makes it clear that Cusa is truly aware of the difficulties a naïve discussion about the Trinity could cause in the Muslim world. It is interesting to observe that the Chaldean interlocutor's concern about monotheism produces a certain backlash in the answer of the Divine Word, who denies that the trinitarian names of the Christian creed are proper names. So Cusa's trinitarian speculation also contributes to a certain demythologization or purification of the Trinity doctrine from popular misunderstandings.

The tools necessary for this demythologization process are unitymetaphysics and negative theology. Thus, since God is beyond any human concept, even religious concepts lose their weight. Accordingly, Cusa's reading of Neoplatonic sources like Proclus ${ }^{49}$ shows his optimism in assuming that religious differences consist much more in a different manner of speaking (in modo dicendi) than in different eternal truths. ${ }^{50}$ Passing from the logical to the ontological level, the cardinal insists on the absolute transcendence, infinity, and oneness of God, who is beyond all otherness. Hence, it is impossible that there is any otherness, i.e., numerical difference between the three divine persons, because numerically different entities would be plural—and therefore, in theological terms, created. In De non aliud, Cusa explicitly remarks: "non aliud est non aliud quam non aliud."51

46 Thierry's use of this triad is vast in his most important works-Commentum, Lectiones, Glosa, and Tractatus de sex dierum operibus - which are edited in Nikolaus M. Häring, ed., Commentaries on Boethius by Thierry of Chartres and his School (Toronto: Pontifical Institute of Medieval Studies, 1971).

47 De docta ign. I, 8-9.

48 Ibid., I, 9.

49 On Proclus, see Werner Beierwaltes, Proklos: Grundzüge seiner Metaphysik, 2nd revised and extended ed., Philosophische Abhandlungen, 24 (Frankfurt: Klostermann, 1979).

50 In the margin 557 to the 7 th book of Proclus' In Parmenidem, Cusa writes: “[... ] videtur igitur subtiliter consideranti. in modo dicendi pocius esse diuersitatem, inter platonicos iudeos cristianos et arabes" (Marg. 557, CUSANUS-Texte: III. Marginalien:2. Proclus Latinus: Die Exzerpte und Randnoten des Nikolaus von Kues zu den lateinischen Übersetzungen der Proclus-Schriften: 2.2. Expositio in Parmenidem Platonis, ed. Karl Bormann: Vorgelegt am 23. Mai 1985 von Werner Beierwaltes, Abhandlungen der Heidelberger Akademie der Wissenschaften: Philosophisch-historische Klasse: Jahrgang 1986: 3. Abhandlung (Heidelberg: Winter, 1986), 136-137).

51 De non aliud 1. 
Within Cusa's unity-metaphysics, the principle of presupposition plays a key role. Thus, in chapter 4 of De pace fidei the Greek interlocutor states that all philosophers presuppose wisdom, ${ }^{52}$ in chapter 5 the Italian holds that God must be wisdom, ${ }^{53}$ and in chapter 6 , the Arab agrees that even polytheists presuppose divinity as the eternal principle in which the particular gods participate. ${ }^{54}$ According to Nicholas of Cusa, the common ground of different religions is absolute oneness, which is explicitly presupposed by monotheists and implicitly presupposed by polytheists. ${ }^{55}$ However, his search for common ground must not be misunderstood as a pluralistic theology of religions, ${ }^{56}$ because he attempts to point out that Christian core doctrines like the Trinity or the Incarnation are also presupposed by people from other religious traditions, especially by Muslims.

If we take another look at the passage cited above from chapter 8 of $D e$ pace fidei, we can understand the reason why Cusa insists on the trinitarian structure of God. Here, he establishes an analogy between the fecundity of the human mind and the fecundity of the divine mind. As the human mind begets wisdom or understanding, the divine mind similarly begets divine wisdom. Like the human mind and wisdom, the divine mind and wisdom are also both connected by will or love. ${ }^{57}$ This analogy is made possible because every creature receives its being and fecundity from its creator, who must therefore be considered fecund as well. 58

\footnotetext{
$52 \quad$ De pace fidei 4 , n. 11.

53 Ibid., 5 , n. 14 .

54 Ibid., 6, n. 17 .

55 On this issue, see Klaus Kremer, "Die Hinführung (manuductio) von Polytheisten zum Einen, von Juden und Mohammedanern zum Dreieinen Gott," in Der Friede unter den Religionen nach Nikolaus von Kues, ed. Rudolf Haubst, thematic issue of Mitteilungen und Forschungsbeiträge der Cusanus-Gesellschaft 16 (1984): 126-163; Markus Enders, "Die eine (wahre) Gottesverehrung in der Vielfalt der Religionen: Zur Begründungsfunktion der spekulativen Einheitsmetaphysik des Cusanus für seine Vision eines immerwährenden Religionsfriedens," in Metaphysik und Religion: Die Wiederentdeckung eines Zusammenhanges, ed. Hermann Deuser, Veröffentlichungen der wissenschaftlichen Gesellschaft für Theologie, 30 (Gütersloh: Gütersloher Verlagshaus, 2007) 119-153.

56 E.g., John Hick and Paul F. Knitter, eds., The Myth of Christian Uniqueness: Toward a Pluralistic Theology of Religions (Maryknoll, NY: Orbis, 1987). Some critical remarks are given in Gavin D'Costa, ed., Christian Uniqueness Reconsidered: The Myth of a Pluralistic Theology of Religions (Maryknoll, NY: Orbis, 1990).

57 De pace fidei 8 , n. 24.

$5^{8}$ Ibid., 8, n. 24.
} 
It appears that the Divine Word tries to convince its Chaldean interlocutor by claiming: Whoever affirms that God is the creator and the fecund source of all, must affirm that he is triune. Evidently, in order to guide its interlocutor to the trinitarian God, the Divine Word does not resort to supernatural sources of revelation or to salvific history, but rather to natural knowledge. In this vein, Cusa follows the Iberic tradition of the Castilian John of Segovia ${ }^{59}$ and the Catalans Raymond Lull ${ }^{60}$ and Raymond of Sabunde, ${ }^{61}$ all of whom saw the urgent need to convert Muslims by proving disputed doctrines like the Trinity through reason. Consequently, Cusa's philosophical translation of the trinitarian doctrine is open to public — but profoundly metaphysical—reason. In this respect, he differs significantly from modern postmetaphysical philosophers like Habermas. ${ }^{62}$

The main problem, though, still needs to be solved: How can Cusanus overcome the apparent contradiction between the negation of otherness in God and the affirmation that God is in fact triune? Following Boethius' $D e$ Trinitate ${ }^{63}$ the cardinal maintains that the trinitarian persons only differ in relation to each other but not in their essence, in contrast to the varying nature of numerically different, finite beings. ${ }^{64}$ Since the Trinitarian figures therefore do not violate absolute unity, they neither multiply God nor limit each other. Hence, the Islamic accusation of shirk is philosophically rejected.

59 On John of Segovia's apologetics, see Darío Cabanelas Rodríguez, Juan de Segovia y el problema islámico (Madrid: Universidad de Madrid, 1952).

6o On Raymond Lull's apologetics, see Viola Tenge-Wolf, "Erstes Kapitel: Allgemeine Einführung," in Doctoris Illuminati Raimundi Lulli Opera latina cum cura et studio Instituti Raimundi Lulli in Universitate Friburgense Brisigavorum ad fidem codicum manu scriptorum edita: Tomus XXVII: 53: Tabula generalis In mari in portu Tunicii in medio septembris anno MCCXCIII incepta et in civitate Neapolis in octavis Epiphaniae anno MCCXCIV ad finem perducta, ed. Viola Tenge-Wolf, Corpus Christianorum: Continuatio Mediaevalis, 181 (Turnhout: Brepols, 2002), 13-52.

61 On Raymond of Sabunde's apologetics, see Walter Andreas Euler, "Raimund von Sabunde," Theologische Realenzyklopädie 28 (1997): 122-125.

62 E.g., Jürgen Habermas, "Ein Bewußtsein von dem, was fehlt," in Ein Bewußtsein von dem, was fehlt: Eine Diskussion mit Jürgen Habermas, ed. Michael Reder and Josef Schmidt (Frankfurt: Suhrkamp, 2008), 26-36. However, it is hard to see why a secular society ought to be necessarily postmetaphysical, as Habermas states (33).

63 Boethius, De Trinitate 5 in Boethius, The Theological Tractates, ed. and trans. H. F. Stewart and E. K. Rand, The Loeb Classical Library (London: Heinemann., 1918), 26-27.

64 De pace fidei 8 , n. 23. 


\section{Why Naming the Trinitarian God is Still Important for Cusa}

This translation of kerygmatic proper names into philosophical concepts should not, however, be misunderstood as a reduction of proper names to definite descriptions, as is done by Russell. ${ }^{65}$ Proper names are constitutive for interpersonal communication, revelation, and religious practice. Contrary to conceiving something, naming someone means getting familiar with him or her. In one of his main theological works, Introduction to Christianity, Joseph Ratzinger points out the difference between a mere philosophical concept of God that points at God's essence, and a name of God that is relevant for religious life, as the latter enables an interpersonal communication with God. ${ }^{66}$ Already in his first lecture held at the University of Bonn in 1959, Ratzinger states that God's accessibility (Ansprechbarkeit) in prayer is one of the most important innovations of monotheism compared to polytheism. ${ }^{67}$ In doing so, he differentiates between the meaning of personality in metaphysics and in philosophy of religion. In terms of metaphysics, even Aristotle's unmoved mover can be called personal, due to his self-reference or self-reflection. However, in terms of philosophy of religion, personality must entail accessibility. 68

Nicholas of Cusa shares both meanings of personality. On the one hand, God is absolutely self-referential. At the same time, God's accessibility is also central to Cusa's thought, testified by many passages ${ }^{69}$ and by the mystagogical framework of his entire oeuvre.

Above all, there always remains a gap between God's First-Person-Speech in revelation, the Second-Person-Speech in prayer, and the Third-Person-Speech in philosophy or theology.

In his book In Excess, Jean-Luc Marion refers to the Jewish tradition of the ineffable name of God, which can never be pronounced as a proper name. ${ }^{70}$

65 On Russell's description theory, see his article "On Denoting," Mind 14/4 (1905): 479-493.

66 Joseph Ratzinger, Einführung in das Christentum: Vorlesungen über das Apostolische Glaubensbekenntnis, 4th ed. (Munich: Kösel, 2005), 122-123.

67 Joseph Ratzinger, Der Gott des Glaubens und der Gott der Philosophen: Ein Beitrag zum Problem der theologia naturalis, ed. Heino Sonnemanns, 3rd ed. (Trier: Paulinus, 2006), pp. 27-28.

68 Ibid., 63, note 7 .

69 E.g., De docta ign. I, 26; III, Prol.; III, 12; De vis. Dei 4 (h VI n. 9)—25 (h VI n. 119); Sermo XXIII (h XVI, 4 n. 37).

70 Jean-Luc Marion, In Excess: Studies of Saturated Phenomena, trans. R. Horner and V. Berraud, Perspectives in Continental Philosophy, 27 (New York: Fordham University Press, 2001), 157 . 
But even in Christianity, this apophatic tradition is still present and deploys a religious transformation of human beings:

For the name no longer functions by inscribing God within the theoretical horizon of our predication but rather by inscribing us, according to a radically new praxis, in the very horizon of God. This is exactly what baptism accomplishes when, far from our attributing to God a name that is intelligible to us, we enter into God's unpronounceable Name, with the additional result that we receive our own. This pragmatic theology is deployed, in fact, under the figure of the liturgy (which begins with baptism), where it is never a matter of speaking of God, but always of speaking to God in the words of the Word. ${ }^{71}$

According to Marion, the essence of Christian theology does not consist in talking theoretically of God, but in talking to God in worship. Since worship presupposes a certain accessibility of God, God must render himself accessible by revealing himself to mankind. Here we must be aware of an important difference between man and God. Human beings always reveal themselves after having been named by someone else, for example parents who choose a certain name and start talking with their child. After some time of getting familiar with words, it is the child who reveals him- or herself as a person by calling or conversing with his or her parents. ${ }^{72} \mathrm{God}$, in contrast, does not need to be named or called by human beings in order to reveal himself as personal. As the trinitarian formula "non aliud est non aliud quam non aliud"73 indicates, it is God who names himself. Although God's proper name, which enfolds the essence of all beings, is absolutely transcendent, ${ }^{74}$ it becomes visible in our contingent world through Jesus Christ, God incarnate. In fact, for Cusa, Jesus is God's proper name. ${ }^{75}$ As universal mediator, he connects divinity and humanity, or, more precisely, he enables the human image to be part of its divine exemplar without being absorbed by it. ${ }^{76}$

\footnotetext{
71 Ibid., 157 .

72 An interesting phenomenological investigation on the correlation between revelation and personality is given in August Brunner, Offenbarung und Glaube: Eine phänomenologische Untersuchung (Munich: Berchmans, 1985), 11-28.

73 De non aliud 1.

74 De docta ign. I, 24.

75 Sermo XXIII, n. 28-40.

76 De vis. Dei 18 , n. 82.
} 
So we can draw the conclusion that Cusa's trinitarian theology finally boils down to a Christology aiming at guiding humans-including people from other religions - to the heart of the Trinity. ${ }^{77}$ In doing so, he differs significantly from contemporary Christian-Muslim dialogue, which excludes proselytism as well as syncretism. Nevertheless, Cusa still shares the Muslim concern about God's unity. Therefore, the Islamic rejection of the trinitarian doctrine plays a key role in Cusa's trinitarian speculation. On the one hand, it serves as a starting point for Cusa's rational apologetic of the Trinity, meant as a response to Qur'anic objections. On the other hand, it helps him to deepen and purify his own trinitarian belief, separating it from popular, especially tritheistic, misunderstandings. In this way, contemporary trinitarian theology could learn a lot from Cusa's awareness that the trinitarian doctrine is still monotheistic. But also, contemporary interreligious dialogue could be reminded that both Christianity and Islam entail an alethic dimension.

77 On the mystical dimension of Cusa's trinitarian speculation see Bernard McGinn, "Unitrinum seu triunum: Nicholas of Cusa's Trinitarian Mysticism," in Mystics: Presence and Aporia, ed. Michael Kessler (Chicago: University of Chicago Press, 2003), 90-117. 